\title{
The gut-kidney-heart axis in chronic kidney disease
}

\author{
K Sumida $^{1}$, CP Kovesdy ${ }^{1,2}$ \\ ${ }^{1}$ Division of Nephrology, Department of Medicine, University of Tennessee Health Science Center, \\ Memphis, TN, USA \\ ${ }^{2}$ Nephrology Section, Memphis VA Medical Center, Memphis, TN, USA
}

Received: August 10, 2019

Accepted: August 21, 2019

The recent explosion of scientific interest in the gut microbiota has dramatically advanced our understanding of the complex pathophysiological interactions between the gut and multiple organs in health and disease. Emerging evidence has revealed that the gut microbiota is significantly altered in patients with chronic kidney disease (CKD), along with impaired intestinal barrier function. These alterations allow translocation of various gut-derived products into the systemic circulation, contributing to the development and progression of CKD and cardiovascular disease (CVD), partly mediated by chronic inflammation. Among potentially toxic gut-derived products identifiable in the systemic circulation, bacterial endotoxin and gut metabolites (e.g., p-cresyl sulfate and trimethylamine-N-oxide) have been extensively studied for their immunostimulatory and atherogenic properties. Recent studies have also suggested similar biological properties of bacterial DNA fragments circulating in the blood of patients with CKD, even in the absence of overt infections. Despite the accumulating evidence of the gut microbiota in CKD and its therapeutic potential for CVD, the precise mechanisms for multidirectional interactions between the gut, kidney, and heart remain poorly understood. This review aims to provide recent evidence on the associations between the gut microbiota, CKD, and CVD, and summarize current understanding of the potential pathophysiological mechanisms underlying the "gut-kidney-heart" axis in CKD.

Keywords: bacterial DNA, cardiovascular disease, chronic kidney disease, constipation, end-stage renal disease, microbiome, permeability, uremic toxins

\section{Introduction}

Chronic kidney disease (CKD) is a significant public health problem worldwide with increasing prevalence and poor outcomes such as cardiovascular disease (CVD), end-stage renal disease (ESRD), and mortality, consuming a disproportionate amount of financial resources $(16,49)$. The increased risk of CVD in patients with CKD is not fully accounted for and supported by traditional cardiovascular (CV) risk factors, such as dyslipidemia, hypertension, and diabetes mellitus (111), and low-grade chronic inflammation, one of the so-called non-traditional CV risk factors, has been implicated as a primary shared risk factor of the excess risk of CVD in this unique population $(2,9,48)$. Considerable efforts have been

Corresponding author: Keiichi Sumida, MD, MPH, PhD

Division of Nephrology, Department of Medicine, University of Tennessee Health Science Center 956 Court Ave., Suite A220, Memphis, TN 38163, USA

Phone: +1 901448 2339; Fax: +1 901448 5513; E-mail: ksumida@uthsc.edu

\footnotetext{
This is an open-access article distributed under the terms of the Creative Commons Attribution-NonCommercial 4.0 International License, which permits unrestricted use, distribution, and reproduction in any medium for noncommercial purposes, provided the original author and source are credited, a link to the CC License is provided, and changes - if any - are indicated.
} 
established to reduce the inflammatory load in patients with CKD primarily by targeting its known causative factors; however, they have been proven largely unsuccessful (39). Hence, the substantial disease burden attributable to inflammation remains unresolved.

Over the past few decades, the characteristics and functions of gut microbiota have been extensively studied, and a number of studies have revealed that the alteration of gut microbiota (i.e., gut dysbiosis) plays a central role in the pathogenesis of many diseases including CKD and CVD, often referred to as the "gut-kidney" and "gut-heart" axes, respectively $(12,74)$. Several factors such as impaired intestinal barrier and gut-derived toxic products have been suggested to contribute to these relationships partly mediated by systemic inflammation (12), suggesting that the gut is a potential cause of CKD-related complications and more importantly could serve as a novel therapeutic target for CVD in CKD (73). However, the precise mechanisms for the possible multidirectional interactions between the gut, kidney, and heart remain poorly understood.

In this review, we describe recent evidence on the association between the gut microbiota, CKD, and CVD and summarize current understanding of the potential pathophysiological mechanisms underlying the "gut-kidney-heart" axis in CKD (Fig. 1).

\section{Composition of the Gut Microbiota}

The human gastrointestinal tract harbors a complex community of more than 100 trillion individual organisms (106). The gut microbiota encodes at least 150 -fold more genes than the human genome, which is also known as the gut microbiome (94). The introduction of highthroughput microbial DNA sequencing technologies has enabled profiling of diverse microbial

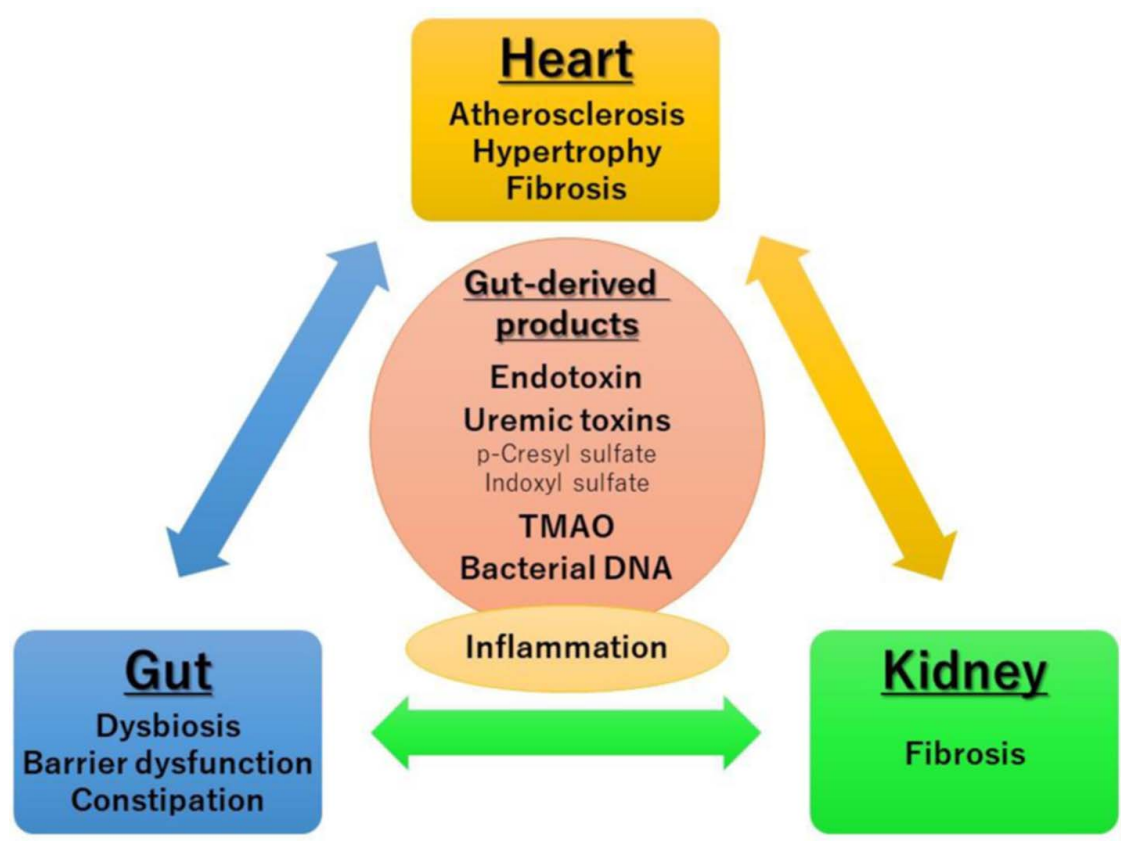

Fig. 1. Schematic representation of the gut-kidney-heart axis. TMAO: trimethylamine-N-oxide 
communities in the gut, providing evidence that the overall composition and abundance of the gut microbiota vary significantly among geographically separated human populations, while dominant members of the gut microbiota are similar across the globe and are independent of race and gender (53). In general, the gut microbiota in healthy adults is dominated by two bacterial phyla, Firmicutes and Bacteroidetes, out of over 50 bacterial phyla; and other bacterial phyla include Actinobacteria, Proteobacteria, Cyanobacteria, and Fusobacteria $(17,93)$. Given a constant diet, the composition of the gut microbiota remains stable over time within an individual (20), which however can be easily altered by changes in diet (14).

\section{Host-Microbiota Interaction in Health and Disease}

For millions of years, the gut microbiota has coevolved with the human host and their proper interactions provide the host with various symbiotic benefits. Under physiological conditions, the gut microbiota participates in a variety of metabolic activities and has thus been recognized as a metabolically active endogenous organ in itself (74). These complementary metabolic activities include synthesis of certain vitamins (30), degradation of undigestible plant polysaccharides and oxalates (32), and biotransformation of conjugated bile acids (34). Therefore, changes in the composition and function of the gut microbiota, such as an increase in Firmicutes to Bacteroidetes ratio, have indeed been associated with numerous disease states including hypertension (1), heart failure (46), CVD (8), and CKD (65).

\section{Short-chain fatty acids (SCFAs) and host physiology}

One of the mechanisms by which the alteration of gut microbiota is linked to these conditions is through reduced production of SCFAs, such as acetate, propionate, and butyrate. SCFAs are the products of bacterial fermentation of plant-derived carbohydrates mainly by Bacteroidetes and Firmicutes (50), and play a vital role in regulating the homeostasis of human body and progression of diseases (64). Specifically, SCFAs serve as important energy resources for colonic epithelial cells (36) and maintain the integrity of the epithelial barrier function by regulation of tight junction proteins including occluding, claudin-1, and zonula occludens-1 (104). Furthermore, SCFAs can protect the intestinal epithelium via enhancement of the modulation of host immune responses by two major SCFA signaling mechanisms: inhibition of histone deacetylases (HDACs) and activation of a certain G protein-coupled receptors (GPRs) $(33,89,95)$. The HDACs are enzymes that prevent DNA transcription and thereby regulate gene expression. Inhibition of HDACs in colonocytes and mucosal immune cells by SCFAs could therefore lead to suppression of the nuclear factor-kappa beta (NF- $\kappa \mathrm{B})$ in several types of cells in the mucosal immune system, thereby influencing transcription of inflammatoryassociated genes, including those that code for proinflammatory cytokines [e.g., interleukin-6 (IL-6) and tumor necrosis factor-alpha (TNF- $\alpha)](10,110)$. In fact, increased NF-kB activation was found in colonic biopsies from patients with Crohn's disease, which was inhibited by applying butyrate to the specimen, accompanied by a reduction in the release of several proinflammatory cytokines $(27,77)$. Meanwhile, the GPRs, particularly GPR43, GPR41, and GPR109A, have been identified as colonic receptors for SCFAs and play a major role in the regulation of inflammatory processes partly through suppressing the expression of NF- $\mathrm{kB}$ and promoting the differentiation of colonic regulatory $\mathrm{T}$ cells $(79,92)$. Of interest, recent studies have shown that SCFAs influence blood pressure regulation partly through GPR41, which is also expressed in the endothelium and is shown to mediate a hypotensive response $(60,68)$. This 
is also supported by the finding that the GPR41 gene-deleted mice developed isolated systolic hypertension with increased vascular fibrosis, increased pulse wave velocity, and cardiac hypertrophy compared with wild-type littermates (60).

Taken together, SCFAs serve as key regulators for modulation of gut integrity, energy homeostasis, immune function, and blood pressure response. Therefore, a state of reduced abundance of SCFA-producing taxa in the gut could in turn negatively affect various disease conditions, such as inflammatory bowel disease, colorectal cancer, hypertension, and $\operatorname{CVD}(5,21)$.

\section{The Gut Microbiota in CKD}

Emerging evidence has revealed that, compared with healthy individuals, patients with CKD show a significant alteration of the gut microbiota, with increased numbers of specific microbial taxa of both aerobic and anaerobic bacteria (78). In a study comparing the composition of the gut microbiota between CKD and control rats, a significant difference was found in the abundance of 175 bacterial operational taxonomic units (OTUs), which are microbial genomic sequences clustered by sequence similarity, with notable decreases in certain families of the Bacteroidetes and Firmicutes phyla, especially Lactobacillaceae and Prevotellaceae families, in the CKD rats (99). The study also revealed a significant difference in the abundance of 190 bacterial OTUs between patients with ESRD and healthy individuals (99). Other studies have shown that the number of Enterobacteriaceae (especially Enterobacter, Klebsiella, and Escherichia), Enterococci, and Clostridium perfringens was significantly higher in the stool of patients with ESRD than healthy controls $(29,103)$.

One of the contributing factors to the gut dysbiosis in CKD may be the uremic milieu. Bacterial urease in the gut, for example, hydrolyzes urea and produces large quantities of ammonia and ammonium hydroxide, which increase luminal $\mathrm{pH}$ and result in the alteration of gut microbial compositions $(98,108)$. Other factors potentially contributing to the altered gut microbiota in CKD include restricted intake of dietary fiber (35), medication use (e.g., antibiotics, phosphate binders, and iron) (42, 47, 96), slow intestinal transit time (109), and metabolic acidosis (24). It may be important to note that most of these factors have also been suggested as causative factors for the intestinal barrier dysfunction, which has recently been increasingly recognized in patients with CKD $(3,55,91)$.

\section{Intestinal Barrier Dysfunction in CKD}

Intestinal barrier dysfunction and bacterial translocation have been well described in certain diseases, such as inflammatory bowel disease (52), portal hypertension (51), and heart failure (101). Emerging evidence has revealed that the intestinal epithelial barrier is altered both structurally and functionally in patients with CKD, resulting in increased gut permeability (55). Several factors have been suggested to account for the gut barrier dysfunction in CKD, including gut dysbiosis $(41,87)$, slow intestinal transit time (109), low dietary fiber intake (44), metabolic acidosis (41), gut ischemia and edema (87), iron therapy (102), and frequent use of antibiotics (15). Urease enzyme produced by certain microbiota families, such as Enterobacteriaceae, for example, hydrolyzes urea in the gut, leading to the formation of ammonium hydroxide. The high amount of ammonium hydroxide could then induce disruption of the intestinal epithelial tight junctions, characterized by the depletion of 
occludin, claudin-1, and zona occludens proteins (99). Recent evidence has also revealed that dysfunction of tight junction proteins results in reduced expression of nuclear factor erythroid 2-related factor 2 (NRF2), a regulator of antioxidant defense genes, thus elevating levels of oxidative stress in the uremic milieu (45). The resultant increase in gut permeability, in turn, allows translocation of gut-derived toxins, bacterial fragments, and intact bacteria through the bowel wall into the systemic circulation, which has been considered as a key contributor to the activation of host inflammatory responses, potentially leading to excess morbidity and mortality in CKD (100).

\section{Gut-Derived Products and CVD in CKD}

Among possible gut-derived products identifiable in the systemic circulation, bacterial endotoxin [i.e., lipopolysaccharide (LPS)], and gut metabolites [e.g., p-cresyl sulfate and trimethylamine-N-oxide (TMAO)] have been extensively studied for their immunostimulatory and atherogenic properties $(19,90,107)$. Recently, using the technique of bacterial DNA amplification, similar biological properties have also been recognized for circulating bacterial DNA fragments among patients with CKD, even in the absence of overt infections (87).

\section{Bacterial endotoxin and CVD in CKD}

Bacterial endotoxin, a LPS constituent of the external cell wall of most Gram-negative bacteria, is continuously produced in the gut and translocated into the systemic circulation across the intestinal barrier $(54,63)$. Patients with CKD are characteristically exposed to significant endotoxemia due to altered gut permeability and/or endotoxin contamination of dialysis water $(23,72)$. A previous study showed that the levels of circulating endotoxin increased with advancing CKD stages, with the highest levels observed in patients receiving dialysis (54). In addition, accumulating evidence has revealed the strong association between endotoxemia and systemic inflammation, which has been implicated in the development and progression of atherosclerosis and subsequent CVD in CKD (22). Toll-like receptor 4 (TLR4), which is expressed on various tissues including cells of the innate immune system, smooth muscle, and endothelial cells and binds to circulating endotoxin, plays a central role in the inflammatory process (63). Endotoxin-mediated signaling through TLR4 stimulates IL-1 receptor-associated kinase via mutant myeloid differentiation primary response 88 and myeloid differentiation protein 2 , and the subsequent recruitment of TNF receptor-associated factor 6 leads to the activation of the NF- $\mathrm{KB}$ and the release of various proinflammatory cytokines $(59,88)$. These inflammatory responses result in endothelial cell injury, transformation of macrophages to foam cells, and procoagulant activity, and could consequently contribute to the development and progression of atherosclerosis (11).

\section{Microbiota metabolites and CVD in CKD}

p-Cresyl sulfate and indoxyl sulfate. Protein fermentation by certain gut bacteria results in the generation of various metabolites, some of which exert toxic effects and thus are called uremic toxins (25). p-Cresyl sulfate and indoxyl sulfate are the two major gut-derived uremic toxins (31). p-Cresyl sulfate, a 188-Da protein-bound solute, originates from sulfation of the intestinally generated p-cresol, which is a colonic fermentation product of the amino acid tyrosine and phenylalanine (13). Intestinal bacteria also have tryptophanase that converts tryptophan to indole, which is subsequently absorbed and metabolized by the liver to indoxyl sulfate (13). Both p-cresyl sulfate and indoxyl sulfate are normally secreted by the proximal 
tubular cells of the kidneys. However, as kidney function declines, these two uremic toxins accumulate progressively and exert deleterious effects on various tissues and organs, such as renal tubular cell damage, endothelial dysfunction, leukocyte activation, coagulation disturbances, insulin resistance, and cardiac fibrosis and hypertrophy $(69,97)$. p-Cresyl sulfate, for example, increases expression of DNA methyltransferases 1, 3a, and $3 b$ isoforms that suppress Klotho gene expression in the renal tubular cells and also induces epithelial-to-mesenchymal transition-like changes through activation of the renal renin angiotensin aldosterone system/ transforming growth factor-beta pathway, contributing to kidney injury and fibrosis $(84,85)$. In addition, it induces nicotinamide adenine dinucleotide phosphate oxidase activity and reactive oxygen species production in cardiomyocytes, enhancing cardiac apoptosis and resulting in diastolic dysfunction (28). In line with these experimental observations, several clinical studies have shown that elevated levels of p-cresyl sulfate and indoxyl sulfate are associated with higher risk of CKD progression, CVD, and mortality $(4,56)$.

Trimethylamine- $\mathrm{N}$-oxide. TMAO is a circulating organic compound derived from the metabolism of dietary L-carnitine and choline by intestinal bacteria, which was recently found to directly promote atherosclerosis in rodents $(38,105)$. Although the precise mechanisms whereby TMAO induces atherosclerosis remain elusive, the prevailing hypothesis is that TMAO causes alteration of cholesterol and sterol metabolism and promotes pro-atherogenic foam cell formation in the arterial wall by increasing the expression of scavenger receptors on macrophages or by restricting reverse cholesterol transport out of these cells $(38,105)$. Recent clinical studies have demonstrated that elevated levels of TMAO are independently associated with future $\mathrm{CV}$ events in non-CKD and non-dialysis-dependent CKD populations (80). Although this association has not yet been well confirmed in the ESRD population receiving hemodialysis (81), most current evidence supports the mechanistic link between TMAO and CV outcomes.

\section{Bacterial DNA fragments and CVD in CKD}

Due to its highly conserved sequence of $16 \mathrm{~S}$ ribosomal RNA gene in the genome, circulating bacterial DNA fragment is the most easily and consistently detectable component that could also be easily discerned from human DNA (87). In recent years, increasing attention has been paid to circulating bacterial DNA fragments for their immunostimulatory properties and novel pathogenic potential for CVD in patients with CKD, particularly among those with ESRD receiving dialysis (87). Bacterial DNA contains unmethylated cytosine-guanine dinucleotide, with two purine $5^{\prime}$ and two pyrimidine $3^{\prime}(\mathrm{CpG})$ terminations. These are structures required to interact with TLR9 (bacterial DNA receptor), which triggers a cell signaling pathway including activation of the mitogen-activated protein kinases and the NF- $\mathrm{BB}$ (43). In polymorphonuclear neutrophils, bacterial DNA exerts profound effects on neutrophil functions by promoting neutrophil trafficking, inducing chemokine expression, regulating expression of adhesion molecules, enhancing phagocyte activity, and rescuing neutrophils from constitutive apoptosis (18). It also promotes the survival of mononuclear cells and induces IL-6 from those cells $(62,75)$. The inflammatory responses induced by bacterial DNA fragments have also been involved in endothelial injury through induction of endothelial cell apoptosis in hemodialysis patients (57). Furthermore, an experimental study has suggested a direct effect of circulating bacterial DNA fragments on the CV system via suppression of cardiac myocyte contraction (66). In fact, some observational studies have demonstrated significant associations of circulating bacterial DNA level with serum C-reactive protein and IL-6 levels and subsequent risk of CV events in patients with 
ESRD (86). Of note, the association with CV events was found to be less substantial for plasma endotoxin (vs. bacterial DNA) levels, suggesting that, compared to plasma endotoxin, which is a cell wall component of only Gram-negative bacteria, circulating bDNA fragments that derive from both Gram-positive and -negative bacteria could play a more predominant role in the development of CVD (87).

\section{Gut Microbiota-Targeted Interventions for CVD in CKD}

Improved understanding of the pathological roles of gut dysbiosis has triggered interest in the development of various therapeutic interventions, which aimed at reestablishing symbiotic status of the gut microbiota or reducing absorption of gut-derived metabolites (73). These include dietary modifications (37) and the administration of probiotics (i.e., live microorganisms) (61), prebiotics (i.e., non-digestible food ingredients) (40), synbiotics (i.e., both probiotics and prebiotics) (26), oral adsorbents (e.g., AST-120) (76), and genetically engineered bacteria (71). Importantly, however, all of these previous studies have examined the therapeutic effect on surrogate measures; hence, it remains unclear whether these interventions actually reduce $\mathrm{CV}$ risk in patients with $\mathrm{CKD}$.

As another gut microbiota targeted intervention for CVD in CKD, laxatives may be a potentially novel treatment option. In patients with $\mathrm{CKD}$, the prevalence of constipation has been reported to be higher than in the general population (7). Since gastrointestinal motility and gut microbiota are closely interrelated and exert reciprocal effects on each other (70), constipation, one of the clinical forms of gut dysbiosis (67), is recently considered to be involved in the pathogenesis of atherosclerosis partly through chronic inflammation induced by bacterial endotoxins (6) and/or gut-derived metabolites (90), potentially contributing to adverse clinical outcomes $(82,83)$. In addition, a recent study demonstrated that lubiprostone, a chloride channel activator used for constipation treatment, ameliorated the CKD progression and the accumulation of uremic toxins by improving the altered gut microbiota in CKD mice (58). Given the high prevalence of constipation, the substantial alterations of gut microbiota in CKD and the increasing roles of the gut in the disposal of uremic toxins with declining kidney function, the administration of laxatives might be a potentially attractive gut microbiota-targeted therapeutic intervention for CVD in patients with CKD.

\section{Conclusions}

While the relationship between gut health and human disease processes has long been recognized, with the earliest evidence dating back to more than 2,000 years ago when Hippocrates famously stated that "All disease begins in the gut," the recent explosion of scientific interest in the gut microbiota has dramatically advanced our understanding of the complex pathophysiological interactions between the gut and multiple organs. Emerging evidence on the association between gut microbiota, CKD, and CVD has provided novel mechanistic insight into the "gut-kidney-heart" axis, emphasizing the importance of the gut as a potential cause of CKD-related complications. Furthermore, these findings have opened new avenues for the development of personalized, gut microbiota-targeted therapeutic strategies for CVD in CKD, which if proved to be effective, will have a substantial impact on the CKD management. More in-depth basic and clinical research is needed to further 
understand the pathophysiological mechanisms underlying the "gut-kidney-heart" axis to ultimately improve the outcomes of patients with CKD.

\section{Acknowledgements}

Dr. CPK is an employee of the US Department of Veterans affairs. The interpretation and reporting of these data are the responsibility of the authors and in no way should be seen as official policy or interpretation of the Department of Veterans Affairs or the US government. The results of this paper have not been published previously in whole or part.

\section{Conflict of interest}

None of the authors have relevant conflicts of interest.

\section{REFERENCES}

1. Adnan S, Nelson JW, Ajami NJ, Venna VR, Petrosino JF, Bryan RM, Jr., Durgan DJ: Alterations in the gut microbiota can elicit hypertension in rats. Physiol. Genomics 49, 96-104 (2017)

2. Akchurin OM, Kaskel F: Update on inflammation in chronic kidney disease. Blood Purif. 39, 84-92 (2015)

3. Andersen K, Kesper MS, Marschner JA, Konrad L, Ryu M, Kumar Vr S, Kulkarni OP, Mulay SR, Romoli S, Demleitner J, Schiller P, Dietrich A, Muller S, Gross O, Ruscheweyh HJ, Huson DH, Stecher B, Anders HJ: Intestinal dysbiosis, barrier dysfunction, and bacterial translocation account for CKD-related systemic inflammation. J. Am. Soc. Nephrol. 28, 76-83 (2017)

4. Barreto FC, Barreto DV, Liabeuf S, Meert N, Glorieux G, Temmar M, Choukroun G, Vanholder R, Massy ZA, European Uremic Toxin Work Group: Serum indoxyl sulfate is associated with vascular disease and mortality in chronic kidney disease patients. Clin. J. Am. Soc. Nephrol. 4, 1551-1558 (2009)

5. Bartolomaeus H, Marko L, Wilck N, Luft FC, Forslund SK, Muller DN: Precarious symbiosis between host and microbiome in cardiovascular health. Hypertension 73, 926-935 (2019)

6. Bowman JD, Surani S, Horseman MA: Endotoxin, toll-like receptor-4, and atherosclerotic heart disease. Curr. Cardiol. Rev. 13, 86-93 (2017)

7. Cano AE, Neil AK, Kang JY, Barnabas A, Eastwood JB, Nelson SR, Hartley I, Maxwell D: Gastrointestinal symptoms in patients with end-stage renal disease undergoing treatment by hemodialysis or peritoneal dialysis. Am. J. Gastroenterol. 102, 1990-1997 (2007)

8. Carding S, Verbeke K, Vipond DT, Corfe BM, Owen LJ: Dysbiosis of the gut microbiota in disease. Microb. Ecol. Health. Dis. 26, 26191 (2015)

9. Carrero JJ, Stenvinkel P: Inflammation in end-stage renal disease - what have we learned in 10 years? Semin. Dial. 23, 498-509 (2010)

10. Chang PV, Hao L, Offermanns S, Medzhitov R: The microbial metabolite butyrate regulates intestinal macrophage function via histone deacetylase inhibition. Proc. Natl. Acad. Sci. U. S. A. 111, 2247-2252 (2014)

11. Cole JE, Georgiou E, Monaco C: The expression and functions of toll-like receptors in atherosclerosis. Mediators Inflamm. 2010, 393946 (2010)

12. Cosola C, Rocchetti MT, Cupisti A, Gesualdo L: Microbiota metabolites: pivotal players of cardiovascular damage in chronic kidney disease. Pharmacol. Res. 130, 132-142 (2018)

13. Cummings JH: Fermentation in the human large intestine: evidence and implications for health. Lancet 1(8335), 1206-1209 (1983)

14. David LA, Maurice CF, Carmody RN, Gootenberg DB, Button JE, Wolfe BE, Ling AV, Devlin AS, Varma Y, Fischbach MA, Biddinger SB, Dutton RJ, Turnbaugh PJ: Diet rapidly and reproducibly alters the human gut microbiome. Nature 505, 559-563 (2014)

15. Dethlefsen L, Relman DA: Incomplete recovery and individualized responses of the human distal gut microbiota to repeated antibiotic perturbation. Proc. Natl. Acad. Sci. U. S. A. 108(Suppl. 1), 4554-4561 (2011)

16. Eckardt KU, Coresh J, Devuyst O, Johnson RJ, Kottgen A, Levey AS, Levin A: Evolving importance of kidney disease: from subspecialty to global health burden. Lancet 382, 158-169 (2013)

17. Eckburg PB, Bik EM, Bernstein CN, Purdom E, Dethlefsen L, Sargent M, Gill SR, Nelson KE, Relman DA: Diversity of the human intestinal microbial flora. Science 308, 1635-1638 (2005) 
18. El Kebir D, Jozsef L, Filep JG: Neutrophil recognition of bacterial DNA and toll-like receptor 9-dependent and independent regulation of neutrophil function. Arch. Immunol. Ther. Exp. (Warsz) 56, 41-53 (2008)

19. Evenepoel P, Meijers BK, Bammens BR, Verbeke K: Uremic toxins originating from colonic microbial metabolism. Kidney Int. Suppl. 114, S12-S19 (2009)

20. Faith JJ, Guruge JL, Charbonneau M, Subramanian S, Seedorf H, Goodman AL, Clemente JC, Knight R, Heath AC, Leibel RL, Rosenbaum M, Gordon JI: The long-term stability of the human gut microbiota. Science 341, 1237439 (2013)

21. Feng W, Ao H, Peng C: Gut microbiota, short-chain fatty acids, and herbal medicines. Front. Pharmacol. 9 , 1354 (2018)

22. Feroze U, Kalantar-Zadeh K, Sterling KA, Molnar MZ, Noori N, Benner D, Shah V, Dwivedi R, Becker K, Kovesdy CP, Raj DS: Examining associations of circulating endotoxin with nutritional status, inflammation, and mortality in hemodialysis patients. J. Ren. Nutr. 22, 317-326 (2012)

23. Goncalves S, Pecoits-Filho R, Perreto S, Barberato SH, Stinghen AE, Lima EG, Fuerbringer R, Sauthier SM, Riella MC: Associations between renal function, volume status and endotoxaemia in chronic kidney disease patients. Nephrol. Dial. Transplant. 21, 2788-2794 (2006)

24. Goraya N, Wesson DE: Acid-base status and progression of chronic kidney disease. Curr. Opin. Nephrol. Hypertens. 21, 552-556 (2012)

25. Gryp T, Vanholder R, Vaneechoutte M, Glorieux G: p-Cresyl sulfate. Toxins (Basel) 9(2), E52 (2017)

26. Guida B, Germano R, Trio R, Russo D, Memoli B, Grumetto L, Barbato F, Cataldi M: Effect of short-term synbiotic treatment on plasma p-cresol levels in patients with chronic renal failure: a randomized clinical trial. Nutr. Metab. Cardiovasc. Dis. 24, 1043-1049 (2014)

27. Hamer HM, Jonkers DM, Vanhoutvin SA, Troost FJ, Rijkers G, de Bruine A, Bast A, Venema K, Brummer RJ: Effect of butyrate enemas on inflammation and antioxidant status in the colonic mucosa of patients with ulcerative colitis in remission. Clin. Nutr. 29, 738-744 (2010)

28. Han H, Zhu J, Zhu Z, Ni J, Du R, Dai Y, Chen Y, Wu Z, Lu L, Zhang R: p-Cresyl sulfate aggravates cardiac dysfunction associated with chronic kidney disease by enhancing apoptosis of cardiomyocytes. J. Am. Heart Assoc. 4, e001852 (2015)

29. Hida M, Aiba Y, Sawamura S, Suzuki N, Satoh T, Koga Y: Inhibition of the accumulation of uremic toxins in the blood and their precursors in the feces after oral administration of Lebenin, a lactic acid bacteria preparation, to uremic patients undergoing hemodialysis. Nephron 74, 349-355 (1996)

30. Hill MJ: Intestinal flora and endogenous vitamin synthesis. Eur. J. Cancer Prev. 6(Suppl. 1), S43-S45 (1997)

31. Hobby GP, Karaduta O, Dusio GF, Singh M, Zybailov BL, Arthur JM: Chronic kidney disease and the gut microbiome. Am. J. Physiol. Renal Physiol. 316, F1211-F1217 (2019)

32. Hooper LV, Midtvedt T, Gordon JI: How host-microbial interactions shape the nutrient environment of the mammalian intestine. Annu. Rev. Nutr. 22, 283-307 (2002)

33. Huang W, Guo HL, Deng X, Zhu TT, Xiong JF, Xu YH, Xu Y: Short-chain fatty acids inhibit oxidative stress and inflammation in mesangial cells induced by high glucose and lipopolysaccharide. Exp. Clin. Endocrinol. Diabetes 125, 98-105 (2017)

34. Hylemon PB, Harder J: Biotransformation of monoterpenes, bile acids, and other isoprenoids in anaerobic ecosystems. FEMS Microbiol. Rev. 22, 475-488 (1998)

35. Kalantar-Zadeh K, Kopple JD, Deepak S, Block D, Block G: Food intake characteristics of hemodialysis patients as obtained by Food Frequency Questionnaire. J. Ren. Nutr. 12, 17-31 (2002)

36. Kasubuchi M, Hasegawa S, Hiramatsu T, Ichimura A, Kimura I: Dietary gut microbial metabolites, short-chain fatty acids, and host metabolic regulation. Nutrients 7, 2839-2849 (2015)

37. Kieffer DA, Piccolo BD, Vaziri ND, Liu S, Lau WL, Khazaeli M, Nazertehrani S, Moore ME, Marco ML, Martin RJ, Adams SH: Resistant starch alters gut microbiome and metabolomic profiles concurrent with amelioration of chronic kidney disease in rats. Am. J. Physiol. Renal Physiol. 310, F857-871 (2016)

38. Koeth RA, Wang Z, Levison BS, Buffa JA, Org E, Sheehy BT, Britt EB, Fu X, Wu Y, Li L, Smith JD, DiDonato JA, Chen J, Li H, Wu GD, Lewis JD, Warrier M, Brown JM, Krauss RM, Tang WH, Bushman FD, Lusis AJ, Hazen SL: Intestinal microbiota metabolism of L-carnitine, a nutrient in red meat, promotes atherosclerosis. Nat. Med. 19, 576-585 (2013)

39. Kooman JP, Dekker MJ, Usvyat LA, Kotanko P, van der Sande FM, Schalkwijk CG, Shiels PG, Stenvinkel P: Inflammation and premature aging in advanced chronic kidney disease. Am. J. Physiol. Renal Physiol. 313, F938-F950 (2017)

40. Koppe L, Fouque D: Microbiota and prebiotics modulation of uremic toxin generation. Panminerva Med. 59, 173-187 (2017) 
41. Koppe L, Mafra D, Fouque D: Probiotics and chronic kidney disease. Kidney Int. 88, 958-966 (2015)

42. Kortman GAM, Reijnders D, Swinkels DW: Oral iron supplementation: potential implications for the gut microbiome and metabolome in patients with CKD. Hemodial. Int. 21(Suppl. 1), S28-S36 (2017)

43. Krieg AM: CpG motifs in bacterial DNA and their immune effects. Annu. Rev. Immunol. 20, 709-760 (2002)

44. Krishnamurthy VM, Wei G, Baird BC, Murtaugh M, Chonchol MB, Raphael KL, Greene T, Beddhu S: High dietary fiber intake is associated with decreased inflammation and all-cause mortality in patients with chronic kidney disease. Kidney Int. 81, 300-306 (2012)

45. Lau WL, Liu SM, Pahlevan S, Yuan J, Khazaeli M, Ni Z, Chan JY, Vaziri ND: Role of Nrf2 dysfunction in uremia-associated intestinal inflammation and epithelial barrier disruption. Dig. Dis. Sci. 60, 1215-1222 (2015)

46. Lau WL, Vaziri ND: The leaky gut and altered microbiome in chronic kidney disease. J. Ren. Nutr. 27, 458-461 (2017)

47. Lau WL, Vaziri ND, Nunes ACF, Comeau AM, Langille MGI, England W, Khazaeli M, Suematsu Y, Phan J, Whiteson K: The phosphate binder ferric citrate alters the gut microbiome in rats with chronic kidney disease. J. Pharmacol. Exp. Ther. 367, 452-460 (2018)

48. Leurs P, Lindholm B, Stenvinkel P: Effects of hemodiafiltration on uremic inflammation. Blood Purif. 35(Suppl. 1), 11-17 (2013)

49. Levey AS, Coresh J: Chronic kidney disease. Lancet 379, 165-180 (2012)

50. Levy M, Thaiss CA, Elinav E: Metabolites: messengers between the microbiota and the immune system. Genes. Dev. 30, 1589-1597 (2016)

51. Lutz P, Nischalke HD, Strassburg CP, Spengler U: Spontaneous bacterial peritonitis: the clinical challenge of a leaky gut and a cirrhotic liver. World J. Hepatol. 7, 304-314 (2015)

52. Maloy KJ, Powrie F: Intestinal homeostasis and its breakdown in inflammatory bowel disease. Nature 474, 298-306 (2011)

53. Martinez I, Stegen JC, Maldonado-Gomez MX, Eren AM, Siba PM, Greenhill AR, Walter J: The gut microbiota of rural Papua New Guineans: composition, diversity patterns, and ecological processes. Cell. Rep. 11, 527-538 (2015)

54. McIntyre CW, Harrison LE, Eldehni MT, Jefferies HJ, Szeto CC, John SG, Sigrist MK, Burton JO, Hothi D, Korsheed S, Owen PJ, Lai KB, Li PK: Circulating endotoxemia: a novel factor in systemic inflammation and cardiovascular disease in chronic kidney disease. Clin. J. Am. Soc. Nephrol. 6, 133-141 (2011)

55. Meijers B, Farre R, Dejongh S, Vicario M, Evenepoel P: Intestinal barrier function in chronic kidney disease. Toxins (Basel) 10, 298 (2018)

56. Meijers BK, Claes K, Bammens B, de Loor H, Viaene L, Verbeke K, Kuypers D, Vanrenterghem Y, Evenepoel P: p-Cresol and cardiovascular risk in mild-to-moderate kidney disease. Clin. J. Am. Soc. Nephrol. 5, 1182-1189 (2010)

57. Merino A, Nogueras S, Garcia-Maceira T, Rodriguez M, Martin-Malo A, Ramirez R, Carracedo J, Aljama P: Bacterial DNA and endothelial damage in haemodialysis patients. Nephrol. Dial. Transplant. 23, 3635-3642 (2008)

58. Mishima E, Fukuda S, Shima H, Hirayama A, Akiyama Y, Takeuchi Y, Fukuda NN, Suzuki T, Suzuki C, Yuri A, Kikuchi K, Tomioka Y, Ito S, Soga T, Abe T: Alteration of the intestinal environment by lubiprostone is associated with amelioration of adenine-induced CKD. J. Am. Soc. Nephrol. 26, 1787-1794 (2015)

59. Moghimpour Bijani F, Vallejo JG, Rezaei N: Toll-like receptor signaling pathways in cardiovascular diseases: challenges and opportunities. Int. Rev. Immunol. 31, 379-395 (2012)

60. Natarajan N, Hori D, Flavahan S, Steppan J, Flavahan NA, Berkowitz DE, Pluznick JL: Microbial short chain fatty acid metabolites lower blood pressure via endothelial G protein-coupled receptor 41. Physiol. Genomics 48 , 826-834 (2016)

61. Natarajan R, Pechenyak B, Vyas U, Ranganathan P, Weinberg A, Liang P, Mallappallil MC, Norin AJ, Friedman EA, Saggi SJ: Randomized controlled trial of strain-specific probiotic formulation (Renadyl) in dialysis patients. Biomed. Res. Int. 2014, 568571 (2014)

62. Navarro MD, Carracedo J, Ramirez R, Madueno JA, Merino A, Rodriguez M, Martin-Malo A, Aljama P: Bacterial DNA prolongs the survival of inflamed mononuclear cells in haemodialysis patients. Nephrol. Dial. Transplant. 22, 3580-3585 (2007)

63. Neal MD, Leaphart C, Levy R, Prince J, Billiar TR, Watkins S, Li J, Cetin S, Ford H, Schreiber A, Hackam DJ: Enterocyte TLR4 mediates phagocytosis and translocation of bacteria across the intestinal barrier. J. Immunol. 176, 3070-3079 (2006) 
64. Nicholson JK, Holmes E, Kinross J, Burcelin R, Gibson G, Jia W, Pettersson S: Host-gut microbiota metabolic interactions. Science 336, 1262-1267 (2012)

65. Pahl MV, Vaziri ND: The chronic kidney disease - colonic axis. Semin. Dial. 28, 459-463 (2015)

66. Paladugu B, Kumar A, Parrillo JE, Der S, Osman J, Mensing J, Falvo L, Xu X, Kumar A: Bacterial DNA and RNA induce rat cardiac myocyte contraction depression in vitro. Shock 21, 364-369 (2004)

67. Parthasarathy G, Chen J, Chen X, Chia N, O'Connor HM, Wolf PG, Gaskins HR, Bharucha AE: Relationship between microbiota of the colonic mucosa vs feces and symptoms, colonic transit, and methane production in female patients with chronic constipation. Gastroenterology 150, 367-379.e1 (2016)

68. Pluznick JL, Protzko RJ, Gevorgyan H, Peterlin Z, Sipos A, Han J, Brunet I, Wan LX, Rey F, Wang T, Firestein SJ, Yanagisawa M, Gordon JI, Eichmann A, Peti-Peterdi J, Caplan MJ: Olfactory receptor responding to gut microbiota-derived signals plays a role in renin secretion and blood pressure regulation. Proc. Natl. Acad. Sci. U. S. A. 110, 4410-4415 (2013)

69. Poesen R, Viaene L, Verbeke K, Claes K, Bammens B, Sprangers B, Naesens M, Vanrenterghem Y, Kuypers D, Evenepoel P, Meijers B: Renal clearance and intestinal generation of p-cresyl sulfate and indoxyl sulfate in CKD. Clin. J. Am. Soc. Nephrol. 8, 1508-1514 (2013)

70. Ponnusamy K, Choi JN, Kim J, Lee SY, Lee CH: Microbial community and metabolomic comparison of irritable bowel syndrome faeces. J. Med. Microbiol. 60, 817-827 (2011)

71. Prakash S, Chang TM: Microencapsulated genetically engineered live E. coli DH5 cells administered orally to maintain normal plasma urea level in uremic rats. Nat. Med. 2, 883-887 (1996)

72. Raij L, Shapiro FL, Michael AF: Endotoxemia in febrile reactions during hemodialysis. Kidney Int. 4, 57-60 (1973)

73. Ramezani A, Massy ZA, Meijers B, Evenepoel P, Vanholder R, Raj DS: Role of the gut microbiome in uremia: a potential therapeutic target. Am. J. Kidney Dis. 67, 483-498 (2016)

74. Ramezani A, Raj DS: The gut microbiome, kidney disease, and targeted interventions. J. Am. Soc. Nephrol. 25, 657-670 (2014)

75. Schindler R, Beck W, Deppisch R, Aussieker M, Wilde A, Gohl H, Frei U: Short bacterial DNA fragments: detection in dialysate and induction of cytokines. J. Am. Soc. Nephrol. 15, 3207-3214 (2004)

76. Schulman G, Berl T, Beck GJ, Remuzzi G, Ritz E, Arita K, Kato A, Shimizu M: Randomized placebo-controlled EPPIC trials of AST-120 in CKD. J. Am. Soc. Nephrol. 26, 1732-1746 (2015)

77. Segain JP, Raingeard de la Bletiere D, Bourreille A, Leray V, Gervois N, Rosales C, Ferrier L, Bonnet C, Blottiere HM, Galmiche JP: Butyrate inhibits inflammatory responses through NFK B inhibition: implications for Crohn's disease. Gut 47, 397-403 (2000)

78. Simenhoff ML, Dunn SR, Zollner GP, Fitzpatrick ME, Emery SM, Sandine WE, Ayres JW: Biomodulation of the toxic and nutritional effects of small bowel bacterial overgrowth in end-stage kidney disease using freezedried Lactobacillus acidophilus. Miner. Electrolyte Metab. 22, 92-96 (1996)

79. Singh N, Gurav A, Sivaprakasam S, Brady E, Padia R, Shi H, Thangaraju M, Prasad PD, Manicassamy S, Munn DH, Lee JR, Offermanns S, Ganapathy V: Activation of Gpr109a, receptor for niacin and the commensal metabolite butyrate, suppresses colonic inflammation and carcinogenesis. Immunity 40, 128-139 (2014)

80. Stubbs JR, House JA, Ocque AJ, Zhang S, Johnson C, Kimber C, Schmidt K, Gupta A, Wetmore JB, Nolin TD, Spertus JA, Yu AS: Serum trimethylamine-N-Oxide is elevated in CKD and correlates with coronary atherosclerosis burden. J. Am. Soc. Nephrol. 27, 305-313 (2016)

81. Stubbs JR, Stedman MR, Liu S, Long J, Franchetti Y, West RE, 3rd, Prokopienko AJ, Mahnken JD, Chertow GM, Nolin TD: Trimethylamine N-oxide and cardiovascular outcomes in patients with end-stage kidney disease receiving maintenance hemodialysis. Clin. J. Am. Soc. Nephrol. (2019) [Epub ahead of print]

82. Sumida K, Molnar MZ, Potukuchi PK, Thomas F, Lu JL, Matsushita K, Yamagata K, Kalantar-Zadeh K, Kovesdy CP: Constipation and incident CKD. J. Am. Soc. Nephrol. 28, 1248-1258 (2017)

83. Sumida K, Molnar MZ, Potukuchi PK, Thomas F, Lu JL, Yamagata K, Kalantar-Zadeh K, Kovesdy CP: Constipation and risk of death and cardiovascular events. Atherosclerosis 281, 114-120 (2019)

84. Sun CY, Chang SC, Wu MS: Suppression of Klotho expression by protein-bound uremic toxins is associated with increased DNA methyltransferase expression and DNA hypermethylation. Kidney Int. 81, 640-650 (2012)

85. Sun CY, Chang SC, Wu MS: Uremic toxins induce kidney fibrosis by activating intrarenal renin-angiotensinaldosterone system associated epithelial-to-mesenchymal transition. PLoS One 7, e34026 (2012)

86. Szeto CC, Kwan BC, Chow KM, Kwok JS, Lai KB, Cheng PM, Pang WF, Ng JK, Chan MH, Lit LC, Leung CB, Li PK: Circulating bacterial-derived DNA fragment level is a strong predictor of cardiovascular disease in peritoneal dialysis patients. PLoS One 10, e0125162 (2015) 
87. Szeto CC, McIntyre CW, Li PK: Circulating bacterial fragments as cardiovascular risk factors in CKD. J. Am. Soc. Nephrol. 29, 1601-1608 (2018)

88. Takeda K, Akira S: TLR signaling pathways. Semin. Immunol. 16, 3-9 (2004)

89. Tan J, McKenzie C, Potamitis M, Thorburn AN, Mackay CR, Macia L: The role of short-chain fatty acids in health and disease. Adv. Immunol. 121, 91-119 (2014)

90. Tang WH, Wang Z, Levison BS, Koeth RA, Britt EB, Fu X, Wu Y, Hazen SL: Intestinal microbial metabolism of phosphatidylcholine and cardiovascular risk. N. Engl. J. Med. 368, 1575-1584 (2013)

91. Terpstra ML, Singh R, Geerlings SE, Bemelman FJ: Measurement of the intestinal permeability in chronic kidney disease. World J. Nephrol. 5, 378-388 (2016)

92. Thangaraju M, Cresci GA, Liu K, Ananth S, Gnanaprakasam JP, Browning DD, Mellinger JD, Smith SB, Digby GJ, Lambert NA, Prasad PD, Ganapathy V: GPR109A is a G-protein-coupled receptor for the bacterial fermentation product butyrate and functions as a tumor suppressor in colon. Cancer Res. 69, 2826-2832 (2009)

93. Tremaroli V, Backhed F: Functional interactions between the gut microbiota and host metabolism. Nature 489, 242-249 (2012)

94. Turnbaugh PJ, Ley RE, Hamady M, Fraser-Liggett CM, Knight R, Gordon JI: The human microbiome project. Nature 449, 804-810 (2007)

95. van der Beek CM, Dejong CHC, Troost FJ, Masclee AAM, Lenaerts K: Role of short-chain fatty acids in colonic inflammation, carcinogenesis, and mucosal protection and healing. Nutr. Rev. 75, 286-305 (2017)

96. Vangay P, Ward T, Gerber JS, Knights D: Antibiotics, pediatric dysbiosis, and disease. Cell. Host Microbe. 17, 553-564 (2015)

97. Vanholder R, Schepers E, Pletinck A, Nagler EV, Glorieux G: The uremic toxicity of indoxyl sulfate and p-cresyl sulfate: a systematic review. J. Am. Soc. Nephrol. 25, 1897-1907 (2014)

98. Vaziri ND: CKD impairs barrier function and alters microbial flora of the intestine: a major link to inflammation and uremic toxicity. Curr. Opin. Nephrol. Hypertens. 21, 587-592 (2012)

99. Vaziri ND, Wong J, Pahl M, Piceno YM, Yuan J, DeSantis TZ, Ni Z, Nguyen TH, Andersen GL: Chronic kidney disease alters intestinal microbial flora. Kidney Int. 83, 308-315 (2013)

100. Vaziri ND, Zhao YY, Pahl MV: Altered intestinal microbial flora and impaired epithelial barrier structure and function in CKD: the nature, mechanisms, consequences and potential treatment. Nephrol. Dial. Transplant. 31, 737-746 (2016)

101. Verbrugge FH, Dupont M, Steels P, Grieten L, Malbrain M, Tang WH, Mullens W: Abdominal contributions to cardiorenal dysfunction in congestive heart failure. J. Am. Coll. Cardiol. 62, 485-495 (2013)

102. Wandersman C, Delepelaire P: Bacterial iron sources: from siderophores to hemophores. Annu. Rev. Microbiol. 58, 611-647 (2004)

103. Wang F, Jiang H, Shi K, Ren Y, Zhang P, Cheng S: Gut bacterial translocation is associated with microinflammation in end-stage renal disease patients. Nephrology (Carlton) 17, 733-738 (2012)

104. Wang HB, Wang PY, Wang X, Wan YL, Liu YC: Butyrate enhances intestinal epithelial barrier function via up-regulation of tight junction protein Claudin-1 transcription. Dig. Dis. Sci 57, 3126-3135 (2012)

105. Wang Z, Klipfell E, Bennett BJ, Koeth R, Levison BS, Dugar B, Feldstein AE, Britt EB, Fu X, Chung YM, Wu Y, Schauer P, Smith JD, Allayee H, Tang WH, DiDonato JA, Lusis AJ, Hazen SL: Gut flora metabolism of phosphatidylcholine promotes cardiovascular disease. Nature 472, 57-63 (2011)

106. Whitman WB, Coleman DC, Wiebe WJ: Prokaryotes: the unseen majority. Proc. Natl. Acad. Sci. U. S. A. 95, 6578-6583 (1998)

107. Wiedermann CJ, Kiechl S, Dunzendorfer S, Schratzberger P, Egger G, Oberhollenzer F, Willeit J: Association of endotoxemia with carotid atherosclerosis and cardiovascular disease: prospective results from the Bruneck Study. J. Am. Coll. Cardiol. 34, 1975-1981 (1999)

108. Wong J, Piceno YM, DeSantis TZ, Pahl M, Andersen GL, Vaziri ND: Expansion of urease- and uricasecontaining, indole- and p-cresol-forming and contraction of short-chain fatty acid-producing intestinal microbiota in ESRD. Am. J. Nephrol. 39, 230-237 (2014)

109. Wu MJ, Chang CS, Cheng CH, Chen CH, Lee WC, Hsu YH, Shu KH, Tang MJ: Colonic transit time in longterm dialysis patients. Am. J. Kidney Dis. 44, 322-327 (2004)

110. Zimmerman MA, Singh N, Martin PM, Thangaraju M, Ganapathy V, Waller JL, Shi H, Robertson KD, Munn $\mathrm{DH}$, Liu K: Butyrate suppresses colonic inflammation through HDAC1-dependent Fas upregulation and Fas-mediated apoptosis of T cells. Am. J. Physiol. Gastrointest. Liver Physiol. 302, G1405-G1415 (2012)

111. Zoccali C, Tripepi G, Mallamaci F: Predictors of cardiovascular death in ESRD. Semin. Nephrol. 25, 358-362 (2005) 